\title{
Devils On and Off Stage: Shifting Effects of Fear and Laughter in Late Medieval and Early Modern German Urban Theatre
}

\author{
Hans Rudolf Velten
}

$\mathbf{1}$

Introduction

Long before the print medium acquired its function of guiding and controlling communication as a means of enforcing a cohesive political system, print had the task of storing and preserving collective knowledge and practices. In the period of transition between a predominantly performative culture and a predominantly textual culture - the fifteenth and sixteenth centuries - the public sphere was constituted by physical media and cultural performances. This 'socialisation among present beings' ('Vergesellschaftung unter Anwesenden') is one of Rudolf Schlögl's central assumptions in his reflections on the development of a public sphere in the early modern period. ${ }^{1}$ Schlögl does not deny the formation and existence of public spheres in late medieval and early modern courts and cities, but he does argue that there was no self-observation in urban performances outside the political process. Urban spaces, he suggested, still lacked a specific discursive medium that was able to reflect upon itself (and that was to become written-print-communication).

The following is an attempt to reassess Schlögl's thesis by examining a single element of one specific form of early modern urban performance, namely German urban theatre. ${ }^{2}$ The element in question is the figure of the devil in

1 Rudolf Schlögl, 'Vergesellschaftung unter Anwesenden in der frühneuzeitlichen Stadt und ihre politische Öffentlichkeit', in Stadt und Öffentlichkeit in der Frühen Neuzeit, ed. by Gerd Schwerhoff (Köln: Böhlau, 2011), pp. 29-38. See also Rudolf Schlögl, Anwesende und Abwesende: Grundriss für eine Gesellschaftsgeschichte der Frühen Neuzeit (Konstanz: Konstanz University Press, 2014). All translations are my own unless otherwise specified.

2 The term theatre embraces both religious and secular drama and performance. There is no doubt that early modern theatre, as an urban event, was subject to the urban public sphere - to its rules and to its discourses - and that theatre could, in turn, influence the rules and discourses of the public sphere. See the introduction to Drama, Performance and Debate: Theatre and Public Opinion in the Early Modern Period, ed. by Jan Bloemendal, Peter G.G. Eversmann, and Elsa Strietman (Leiden: Brill, 2013), pp. 1-18. 
relation to its ritual and religious functions in German plays of the fifteenth and sixteenth centuries, focusing on laughter as a form of communication between characters and audiences. Laughter circulates not only between certain performative occurrences and audiences, but also between the play and public order (as part of the public sphere) in early modern cities. As I hope to show, not only performative occurrences of laughter (humour) but also laughter itself-as a 'performative statement' - can be transformed and used in other cultural contexts, thus becoming a means of self-reflective activity.

In late medieval and early modern plays, devils - and, with them, other negative and foil-like characters like quacks, tomb guards, and Jews-are omnipresent. Not only in plays about the Antichrist and the Last Judgment, but also in Easter and Passion plays, devils have had a significant role as symbolic enemies of God and as reminders of timeless evil in the world. In contrast to the other characters in religious plays, devils distinguished themselves by excessive performances: loud shouting, laughing, and moaning; uncontrolled and fast motoric and proxemic movements like jumping, running, and limping across the open stage; obscene speech and behaviour; grotesque gestures and verbal expressions; and elaborate costumes resulting in a high level of disguise. Devils dance gleefully at every opportunity; try to harm Jesus and his followers; and recruit as many sinful souls as they can. At the same time, their efforts are mostly fruitless: they fail to realise their common goals; they fight and mock each other; they do not listen to the commands of their leader Lucifer; and, thereby, they display the deficiencies of the hellish order.

The Ambivalences of Medieval Religious Drama: so reads the English title of Rainer Warning's 1974 book Funktion und Struktur. Die Ambivalenzen des Geistlichen Spiels. This title also suggests the ambivalence of the devil's role in religious late medieval plays - the ambivalence of fear and laughter, terror and relief, real danger and mere foolishness. ${ }^{3}$ When German medievalists study the interpretation of late medieval plays, they must take Warning into consideration, as he was the first scholar to acknowledge a ritual layer in the religious play: he ascribed the strong opposition between God and the Devil in the dramatic structure of the medieval religious play to an archaic dualism that the kerygmatic liturgy had defined. He demonstrated, therefore, that the staging of Easter and Passion plays resulted in a monumental re-mythologisation of salvation history.

In Warning's theory, the Devil plays a much more significant role in drama than in liturgy or in liturgical plays. As an anthropological antagonist to God,

3 Rainer Warning, The Ambivalences of Medieval Religious Drama, trans. by Steven Rendall (Stanford: Stanford University Press, 2001), p. $102 \mathrm{ff}$. 
he is also the impersonation of terror, a fact that had a strong impact on audiences but could be overcome by ritual laughter at a finally defeated enemy: the figure of the risible devil not only exposes his groundless claim for power, but also addresses the pagan fear of demons, which had been excluded by Christian ideology but was still present in folkloristic belief. Warning supported this argument with the 'Harrowing of Hell', which almost every Easter and Passion play contains: the risen Jesus descends to Hell, breaks open its gates (tollite portas), chains Lucifer, and frees the Old Patriarchs. Lucifer and his devils restock Hell by collecting damned souls. The canonical gospels mention none of these episodes. The 'Harrowing of Hell' was taken from the Gospel of Nicodemus, one of several early Christian gospels that medieval clerics who knew Latin read for information about Christ's life, and that scholars later dropped from the canon as apocryphal. In the 'Harrowing of Hell', which he classifies as a 'staged ritual', Warning sees a gateway to other comical scenes in which devils participate, such as the collecting of souls.

The question remains: Why does the Devil become such a ridiculous figure, if he is meant to be the antagonist of God? Warning himself speaks of a discrepancy between the represented powerlessness and factual omnipotence of the Devil. The problem of coping with evil in relation to laughter has been resolved (or left unresolved) in a variety of ways. Warning himself judges laughter at the Devil as a ritual expression of an archaic Easter joy, that is provoked by the defeat of the old by the new. Laughter thus arises not so much from the Devil's powerlessness, but as a response to the overcoming of his power. The Devil's fruitless efforts to fill up hell by collecting souls can be seen (in Warning) as an answer to the descensus - laughter as an answer to a situation that is otherwise unmanageable. The Devil must be simultaneously powerful and ridiculous or he cannot be ritually defeated.

Friedrich Ohly has vehemently rejected Warning's thesis, pointing to the Christian roots of the Easter play. ${ }^{4}$ The Devil was always present in medieval theology, Ohly reminds us, and it would be false to remove him from an archetypical ritual context. Ohly, however, says little about the ambivalence of fear and ridicule, so questions still remain: Why was staging the Devil in religious urban plays so attractive to directors and to urban theatre performance organisers? Does the Devil fail at his goals and become ludicrous for his exemplary

4 Friedrich Ohly, 'Rainer Warning: Funktion und Struktur', in Romanische Forschungen, 91 (1979), pp. 111-41. See also Walter Haug, 'Rainer Warning, Friedrich Ohly und die Wiederkehr des Bösen im geistlichen Schauspiel des Mittelalters', in Ritual und Inszenierung: Geistliches und weltliches Drama des Mittelalters und der Frühen Neuzeit, ed. by Hans-Joachim Ziegeler (Tübingen: Niemeyer, 2004), pp. 361-74. 
superbia, as Klaus Ridder states? ${ }^{5}$ Can laughter alone lead to redemption, as Peter Berger holds, or can laughter, as an exorcising ritual process, make the Devil's defeat come true, as Bruno Quast suggests? ${ }^{6}$

In the following analysis, I focus less on the symbolic or structural analysis of devil characters in religious and secular plays, in favour of inquiring instead into their performance: their physical behaviour; their relation to the audience; their permeability, all of which I explore from different perspectives and in different theatrical contexts, including Shrovetide and Neidhart plays as well as carnival performances. What was the impact of devils on the audience? What functions and effects did their staging have in the eyes of late medieval playwrights and directors? What kind of laughter did devil performances generate? These are some of the questions to which I would like to briefly sketch answers, beginning with examples from two significant religious plays from the sixteenth century: the three-day Alsfeld Passion play (performed in 1501, 1511, and 1517) and the 1583 Lucern play of the Last Judgement.

\section{$2 \quad$ Religious Plays}

My first example is from the Alsfeld Passion play. With 8,095 lines, many incipits of German and Latin songs, and plenty of stage directions this was one of the longest and most complex plays in German religious theatre. Like every largescale medieval drama it was performed on an open stage (Simultanbühne), which enabled the director to present actions simultaneously on the different parts of the stage and scaffolds. In Easter and Passion plays, simultaneous staging highlighted a powerful contrast between antagonistic forces and between the sacred and the profane. The mansion at the mouth of hell-the gaping jaws of a monster dragon belching smoke and emitting an infernal racket-is to be found, in virtually all religious plays, standing opposite the elevated mansion of heaven erected in the East. The Alsfeld Passion play of 1501 reveals some details that permit us to reconstruct the fairly simple set for hell, which had a door that could be locked firmly with bolts-bolts that Jesus breaks open when harrowing hell and fettering Luciper. The set must also have contained at least one window, since Luciper at one point looks outside.

5 Klaus Ridder, 'Erlösendes Lachen: Götterkomik, Teufelskomik, Endzeitkomik', in Ritual und Inszenierung, ed. by Ziegeler, pp. 195-206.

6 Bruno Quast, Vom Kult zur Kunst. Öffnungen des rituellen Textes in Mittelalter und Früher Neuzeit (Tübingen: Francke, 2004), pp. 124-139. 
From the beginning of the text, it is clear that the devils did not limit themselves to the space of their mansion, but that instead they took over the whole stage, right up to its margins, where they were used as a sort of theatre police. In his prologue, the Proclamator threatens any potential disturbers of the play as follows:

ich wyl uch vorkundigen eyn gebott, das der her schultheys thut: wer da betredden wirt in dissem kreyß, er sij Heyncz adder Concz adder wie er heyß, der do nit gehoret in dit spiel, (vor war ich uch das sagen wel!) der muß syn buße groiplich entphan: mit den tufeln muß er yn die helle gan! ungefug sal nymmant hie triben, wel hie anders yn der herren holde bliben!

I wish to make known a proclamation from the mayor: whoever would enter into this circle be he Heinz or Kunz or whatever his name, who does not belong in this play, (I tell you this in truth!) will be severely punished: with the devils he will have to go to hell! No one can behave raucously here and remain in favour with the city council! ${ }^{7}$

The threat that anyone setting foot on the stage would be seized by devils and dragged into hell puts sinner characters within the plot and transgressors of theatre rules during the performance on the same level: here the play and social order overlap, almost merging with each other. Hans-Jürgen Linke sees this admonition as a response to audience behaviour: ${ }^{8}$ The organisers of the play wanted to ensure that the audience follows the plot, attending to it with the necessary religious seriousness rather than talking, shouting, or laughing. The danger of loud, disruptive expressions of fear, joy, and astonishment was real, especially when we imagine some six to eight thousand spectators packed into the Alsfeld marketplace. In fact, similar threats and admonitions appear very often in religious play texts. Audience members were not to laugh in cases where actors mispronounced or forgot their lines, or moved in the wrong way. Such incidents could easily leap over the thin border between performance

7 The Alsfeld Passion Play (1501), ed., trans., and introd. by Larry E. West (Lewiston: Mellen, 1997), l. 109-18.

8 Hans-Jürgen Linke, 'Sozialisation und Vergesellschaftung im mittelalterlichen Drama und Theater', in Das Theater des Mittelalters und der Frühen Neuzeit als Ort und Medium sozialer und symbolischer Kommunikation, ed. by Christel Meier, Heinz Meyer, and Claudia Spanily (Münster: Rhema, 2004), pp. 63-93 (p. 83). 
and reality, and have actual social consequences, as stated by the Praecursor in the Tyrolian Ascension and Pentecost play of 1517:

Vnnd treibt daraus nit eur gespett So ainer jn reymen misseredt [...] Das ainer sein reim nit wol khann so hennckt jm der ain klämfle an.

And do not mock yourself if someone fails to say his rhyme And if someone does so, do not make a rumour out of it. ${ }^{9}$

Here the dramatic action of the play exceeds its limits and becomes social action, commentary potentially turning into gossip the next day. In this example, instead of the dramatic character the actor-a real person who has made a mistake-becomes visible to the audience. Even if medieval theatre was not a theatre of illusion, interruptions like this one could distort the salvific space that the play was intended to establish. ${ }^{10}$

The Freiburg city council protocols state more than once that, during the play, no one should be mocked or ridiculed: 'To do everything with diligence, so that nobody be mocked' ('alle ding mit vleiß bestelt und versehen, damit man khein spott einlege'). ${ }^{11}$ Audience laughter and derisive talk, in other words, was viewed as a danger to the play's success. We can thus immediately grasp a differentiation in laughter types: ritual laughter about devil figures that focused on the action and derisive laughter at actors' mistakes and unexpected onstage incidents aimed more at the performance than at the salvific narrative.

What information is provided by the records concerning the actors who impersonated devils and, specifically, their social status and profession? Only in some cases do we have evidence to answer this question. For Alsfeld, we are lucky to have an almost complete register of the actors from the performances of 1511 and 1517. Approximately 177 roles can be identified, and when Dorothea Freise studied the city records she found some interesting facts concerning

Tiroler Himmelfahrt- und Pfingstspiel (Tyrolian Ascension and Pentecost-Play) (1517), in Die geistlichen Spiele des Sterzinger Spielarchivs, according to the manuscripts ed. by Walter Lipphardt and Hans-Gert Roloff (Bern: Lang, 1990), IV, pp. 257-300, 366-75, vv. 83-88.

10 See Glenn Ehrstine, 'Präsenzverwaltung: Die Regulierung des Spielrahmens durch den Proklamator und andere expositores ludi', in Transformationen des Religiösen: Performativität und Textualität im geistlichen Spiel, ed. by Ingrid Kasten and Erika FischerLichte (Berlin: De Gruyter, 2007), pp. 63-79.

11 Excerpt from the council protocols of the city of Freiburg, cit. from Johannes Janota, 'Repraesentatio peccatorum: Zu Absicht und Wirkung der spätmittelalterlichen Passionsspielaufführungen', Zeitschrift für deutsches Altertum, 137 (2008), pp. 439-70 (p. 449). 
devil's roles. ${ }^{12}$ Surprisingly, they were played by men of every age and of every social status. Four of the devil-playing actors were in fact among the most venerated citizens of Alsfeld: Jost Spede, Wigant Thuchscherer, Frebinus Erart, and Jost Snider. The only social group that did not take devil roles was the clergy. The organisers tried to prevent identifications between actor and role, when they attributed some of the central characters of the evil to laymen whose religious engagement was beyond any doubt.

Returning now to the beginning of the play, we may note that, in visual support of the Proclamator's warning not to be disruptive, the first figure appearing on stage was Luciper. He was directed to climb up onto his barrel and to call for his devils, who then flocked to him from all over the stage: 'And then all the devils stand in circle around the barrel, singing and chanting' ('Et tunc omnes dyaboli circeunt doleum corisando et cantando').13

This staged image of the omnipresence of evil as hidden yet everywhere, as well as the devils' noisy appearance, strengthens the Proclamator's initial warning-fear is thus instituted as the play's main emotion via dramaturgic audio-visuals: sight, sound, and movement. At the outset of the play, indeed, two kinds of fear come together: the fear of being thrown into the staged mouth of hell set (in the case of audience members trespassing onto the stage) and the parallel religious fear of being thrown into very real hell (by failing, in their real-world lives, to achieve salvation). Both kinds of fear would have been provoked by the audience's perception of the gruesome, loud, and fierce-looking devils who populated the stage. ${ }^{14}$ But soon this fear was to vanish, replaced by relief: the next scene shows Sathanas (Satan) disguising himself as an old woman in order to approach Herodias in an attempt to convince her husband to have John the Baptist beheaded. This may well have set up a special tension between the two characters - possibly causing the audience to snicker-since Herodias was played by a male actor dressed as a woman.

12 Dorothea Freise, Geistliche Spiele in der Stadt des ausgehenden Mittelalters: FrankfurtFriedberg —Alsfeld (Göttingen: Vandenhoeck \& Ruprecht, 2002), pp. 322-27.

13 The Alsfeld Passion Play, ed. by Larry West, after v. 137.

14 Röcke points to the violence as a central issue of the hellish order: Werner Röcke, 'Höllengelächter und Verlachen des Teufels: Inversionen von Lach- und Gewaltgemeinschaften im geistlichen Spiel des Spätmittelalters', in Gewaltgenuss, Zorn und Gelächter: Die emotionale Seite der Gewalt in Literatur und Historiographie des Mittelalters und der Frühen Neuzeit, ed. Claudia Ansorge et al. (Göttingen: V\&R, 2015), pp. 130-62. 
Luciper respondit: Synt du es dan, Sathan, wylt bestan, ßo nym und hencke den mantel an und winge das duch um dyn heubt: die frawe dir destu baß gleubet!

Luciper answers: Satan, since you will take this upon yourself, take the cape and put it on, and wind the cloth around your head; in this way the woman will believe you better!

Et porrigit sibi pallium cum pepulo, et Sathanas recipit et induit dicens:

And he offers his cloak and robe, and Satan takes them and puts them on saying:

Herre, her, ßo ziege ich an die wat: laß sehen, wie woln sie mer dan stad!

My lord, I put on the garment thusly Let's see how it looks on me! $!^{15}$

At this point in the action, the smaller devils put the dress on Satan and mock him for his feminine looks, saying 'he just looks like a wicked woman!, ${ }^{16}$ and he begins to dance towards the court of Herod while the other devils run to the mouth of hell.

Satan may well have caused smiling and laughter in the audience for his worldly modes and 'secret' goals - which would have been made transparent to the spectators. The laughter here may have been ritual, but it is more likely to have come from specific comedic action: on the one hand, from the farcical disguise; on the other, from the staging of different knowledge between audience and character - a 'split situation' in which the audience already knows Satan's plans whereas the characters on stage do not. ${ }^{17}$ A similar humorous motivation for laughter can be seen in the way the devils made themselves

\footnotetext{
15 The Alsfeld Passion Play, ed. by Larry West, vv. 686-91.

16 Ibid., vv. 694.

17 The term 'split situation' ('Situationsspaltung') was coined by Konrad Ehlich to illustrate the interference of two different communicative situations, one inside the text, and one outside. See Konrad Ehlich, 'Text und sprachliches Handeln: Die Entstehung von Texten aus dem Bedürfnis nach Überlieferung', in Schrift und Gedächtnis: Beiträge zur Archäologie der literarischen Kommunikation, ed. Aleida Assmann, Jan Assman, and Christof Hardmeier (Munich: Fink, 1983), pp. 24-43.
} 
appear ridiculous when dealing with sinners of different social classes. ${ }^{18}$ As we have seen, fear and laughter are not usually simultaneous emotions, but they appear syntagmatically separated and alternate with each other throughout the performance. Furthermore, not all occasions for laughter are located in a 'ritual' context of good and evil; instead, they respond to ancient theatrical, carnivalesque, and even literary means such as disguise, cross-dressing, and the 'split situation'.

If we turn for a moment from Alsfeld to another local theatre tradition, namely that of Lucerne in Switzerland, we can learn more about the physical appearance of devils on stage. Traditionally, devil characters displayed hybrid elements like horns, tails, and hoofs; were mostly black or wore black cloth; and had a devil's mask. In sixteenth-century Lucerne, Protestant directors like Renward Cysat and Zacharias Bletz stressed the more human traits of the devil, ignoring both the beast traits and the mask. For his extensive 1583 Passion play (over 12,000 lines and more than 300 roles in a performance lasting 24 hours), Cysat left us copious notes as to the kinds of features he was looking for in the actors he wished to engage. Lucifer was to be a proud and fierce-looking man, and his devils were to be physically strong men who were able to leap about in spectacular ways. ${ }^{19}$ The Lucerne hell was in a small alley next to the wine market where the stage was located, in which devils hid, only to rush out into the market at a signal. According to the stage directions, Satan was fettered with a long chain and when, on the second day, he was freed by the Salvator, he jumped all around the stage like the others. In Lucerne, therefore, the performative aspect of the devil characters becomes evident: they led away and imprisoned souls amidst loud shouting and singing, leaping and jumping, and a series of demoniac goings-on: 'dann hywlent die tüffel, hand ein seltzams springen', the devils howled and jumped around in strange ways. ${ }^{20}$

The best record we have from an eyewitness is a report by Angelo Rizio, the Italian legate of Emperor Charles v, who was present at a performance of the Lucerne play of the Last Judgment (Easter 1549):

18 This also occurs in the lengthy play of catching souls (Seelenfangspiel) in Das Redentiner Osterspiel: Mittelniederdeutsch / Neuhochdeutsch (1464), ed. by Brigitta Schottmann (Stuttgart: Reclam, 1975), vv. 1044-2025.

19 M. Blakemore Evans, Das Osterspiel von Luzern: Eine historisch-kritische Einleitung, trans. by Paul Hagmann (Bern: Theaterkultur-Verlag, 1961), p. 92.

20 Renward Brandstetter, 'Die Technik der Luterners Heiligenspiele: II. Das Spiel von 1549', Archiv für das Studium der neueren Sprachen und Literaturen, 72 (1886), pp. 383-418 (pp. 404-05). 
Li dannati furno condutti all'Inferno da tutti li diavoli circundati con una grossa catena di ferro, et in quello atto fu fatto uno grande applauso per detti diavoli, et nell'Inferno uno strepito grandissimo con fochi diversi et tiri d'artiglieria che pareva volesse minare il mondo.

The devils belted the damned with a thick iron chain and led [them] to hell. At seeing this, the surrounding audience cheered loudly at the devils. But in hell there was a terrific noise coming from fires and gun salutes so that it seemed the world would break into pieces. ${ }^{21}$

This may be a late example of ritual laughter if we assume that, together with applause for the devils' chaining and deporting of the damned into hell, there was also loud, joyful laughter from the audience. Still, there remains a doubt: what if such a response were mere Schadenfreude - the people's malicious enjoyment of even princes, bishops, and kings being forced to follow wild devils to eternal damnation?

The Lucerne records here confirm a tendency that we can observe over the course of the entire sixteenth century: a continuous process of both theatricalisation (in the sense of role-awareness) and entertainment of the devil character. The Devil himself still caused fear and apprehension, but as the century wore on and comic effects increased among the rioting groups of devils on stage, these came to lose their status as a ritualised threat and instead became more and more entertaining. ${ }^{22}$ Moreover, the assignment of other tasks to devil characters-leading souls into hell in the play mirrored devils' real roles as police-like representatives of the urban authority that sought to secure and maintain orderly performances - transformed performative action into social action. Devil characters thus left the frame of salvation to carry the ambivalence of terror and laughter into urban social spaces. This process can also be

21 Angelo Rizio, account in Italian, in Leonhard Haas, 'Über geistliche Spiele in der Innerschweiz', Zeitschrift für schweizerische Kirchengeschichte, 47 (1953), pp. 113-22 (p. 120).

22 Ursula Schulze proposes that the ritual character of religious plays underwent a process of dissolution in the sixteenth century. She gives two reasons: first, a questioning of the salvation effect among audience members, and second, a resulting change in patterns of behaviour during performances - that is, a lack of the necessary receptive attitude: 'das Publikum die ihm zugewiesene Rolle nicht mitspielt, sodass die erforderliche verinnerlichende Rezeption ausbleibt.' Ursula Schulze, 'Formen der Repraesentatio im Geistlichen Spiel', in Mittelalter und Frühe Neuzeit: Übergänge, Umbrüche und Neuansätze, ed. Walter Haug (Tübingen: Niemeyer, 1999), pp. 312-56 (p. 356). 
traced in the secular tradition in, for instance, Neidhart and Shrovetide plays, which I will address next.

In this section, I will look briefly at the contemporary secular tradition, where we can observe a similar transformation and gradual dissolution of the traditional devil character. Many Shrovetide and some Neidhart plays use material from religious drama and deploy contrafacta of devil scenes in their performative structure. I will present three short examples.

In the Großes Neidhartspiel (Tyrolia, c. 1490), a play which depicts the antagonistic relationship between the knight Neidhart and his peasant enemies, devils have lost much of their power to arouse anxiety because they are equated to the latter. The devil scene is not here introduced by a 'Harrowing of Hell', but by a 'confession farce' in which one peasant confesses, on behalf of all the peasants, his hatred for Neidhart, who appears on stage as a priest in disguise. Neidhart-as-priest makes the peasants drunk, cuts their hair into tonsures, and makes them believe that they are monks. After three days - an allusion, of course, to Jesus's three days in the tomb - they rise from their drunken stupor and think they are in hell. Scholars have assumed that, in order to aid this (false) perception, a mouth of hell set was erected on stage, just like in the religious plays. But instead of being captured by the devils, the peasantmonks drag them into a conflict with the knights. The peasants and devils then start to dance with one another and their dances - which until then had had a syntagmatic framing function between the pranks - seem to have completely overtaken the stage. Indeed, the peasants, who have peg-legs (Neidhart had earlier chopped off their left legs as a punishment), become in this dance very like the devils, who have hooves. The scene has been interpreted as a diabolical dance that would have occurred during the arrival of the sin-laden peasants in front of the mouth of hell. Satan had collected the peasants' legs and is keeping them as collateral for the peasants' souls. ${ }^{23}$ According to Cora Dietl, the peasants have sinned by being envious ('neidisch') of Neidhart and by arguing with an 'envy devil' ('Neidteufel') among them. Dietl holds that, because of its allusions to the motifs and patterns of religious plays, the Neidhart play enabled

23 Cora Dietl, "Tanz und Teufel in der Neidharttradition: "Neidhart Fuchs" und "Großes Neidhartspiel”, Zeitschrift für deutsche Philologie, 125 (2006), pp. 390-414 (p. 407). 
audiences to merge into a community of believers that saw the peasants on stage as part of the diabolical community (in an Augustinian sense). ${ }^{24}$

But Dietl overlooks the fact that analogies to the Easter plays are here inverted and transformed into parody: there is no salvation for the audience, as members of both groups-devils and peasants—have become completely grotesque figures, thrashing and cursing at each other. The devils have lost their power because they no longer act as representatives of a transcendent evil. Stage action that is almost nonsensical and completely in the service of the audience's amusement annihilates symbolic meaning. The Neidhart play, which has urban roots and follows an urban ideology, stages the fight between knights and peasants as outdated and depicts its senselessness, making it a matter deserving of laughter. I do not therefore agree that the devils' dance represents their diabolical nature. The performative aspect of the dance makes it ridiculous, and the devils work as instigators of the even more ridiculous peasants. The occasion for laughter here comes from bodies on the stage, not at all from the ritual of salvation. It is their motoric hyperagility which makes these characters ridiculous: rushing and running around had long been the way ludicrous figures like servants and devils moved on stage, and the peasants' and devils' one-legged dance makes it all hypertrophic - a performative example of Mikhail Bachtin's model of the grotesque body, which is a source of laughter and ridicule. ${ }^{25}$

The Nuremberg Fastnachtspiel 'Keller 56', a mid-fifteenth-century Shrovetide play, begins as follows: 'Here starts a play of three evil women who stole cattle from hell' ('Hier gebt sich ain spil an von dreien pösen weiben, die nehmen das vich vor der helle'). ${ }^{26}$ Three ugly old women get drunk at an inn where they learn that a herdsman and his cattle went to hell to try to convince the devils to buy the innkeeper's wine. The women, who have boasted about their reluctance to pay the conjugal debt to their husbands, sneak off without paying and decide to play a prank by stealing the herdsman's cattle. Lucifer,

24 Dietl generally asserts the theological function of dancing in religious plays: 'Dancing Devils and Singing Angels: The Disparate Qualities of Dances in Hessian Religious Plays', European Medieval Drama, 14 (2010), pp. 25-45.

25 See Hans Rudolf Velten, 'Grotesker und komischer Körper: Für ein performatives Körperkonzept', in Der komische Körper. Szenen—Figuren—Formen, ed. by Eva Erdmann (Bielefeld: transcript Verlag, 2003), pp. 145-53 (p. 152).

26 Fastnachtsspiele aus dem 15. Jahrhundert, ed. by Adelbert von Keller, 4 vols (Stuttgart: Bibl.d.litt. Vereins, 1853-1858; repr. Darmstadt: Wiss. Buchg., 1965-1966), I, no. 56, pp. 483-96 (p. 483); subsequent references to this play in the text and notes are to ' $\mathrm{K} 56$ '. See also Ute von Bloh, 'Vor der Hölle: Fastnachtspiel (Keller $5^{6}$ )—Osterspiel—Emmausspiel', in Ritual und Inszenierung, ed. by Ziegeler, pp. 233-46. 
who has befriended the herdsman, sends his devilish assistants to get the cattle back, but the women escape with the herd, and Lucifer's devils come back to hell empty-handed.

Here we have carnivalesque inversions of all sorts: the women break the rules of marriage and of the household hierarchy by turning their husbands into cuckolds; in fact, they behave like bad husbands themselves by drinking, swearing, and stealing, yet calling themselves 'three strong heroes' ('starker helden drei'). ${ }^{27}$ The devils in the play are not gruesome and terrible at all; instead, they are ridiculous in their kind-hearted friendliness. In the end, Harlire, one of the women, announces that even the Devil is inferior to 'the old evil women' ('alten pösen weiben'). ${ }^{28}$ What the devil could not manage they would bring about by 'working magic and cooing' ('zaubern und auch kosen') and by 'lying, deceiving, and swearing' ('liegen triegen und swern'). ${ }^{29}$ In a word, the women's abilities are more powerful and devastating than those of the empty-handed devils.

This text is organised in dialogue with elements from religious plays; it provides almost demonic contrafacta to the visitatio and descensus scenes of the Easter and Passion plays: ${ }^{30}$ the three women represent the three holy Marys in the Mercator scene, which is a central catalyst for laughter in many Easter plays; the rape of the cattle refers to the liberation of the righteous from hell; and the devils' inability to bring back the cattle parodies and inverts their power to refill hell with sinful people. This Shrovetide play takes the devil plays as a matrix from which to create a parodistic assemblage that reduces devil characters to ridiculousness, as von Bloh has stated. ${ }^{31} \mathrm{~A}$ salient example is the Innsbruck Easter play, in which Lucifer mourns an attack on his reign with furious cries: 'Fellows, dear fellows, we have lost all our souls' ('Gesellen, liben geselen alle, [...] wir haben dy selen vorlorn'), summoning them in order to collect new souls. ${ }^{32}$ In $\mathrm{K}_{5} 6$, similar lines read:

$27 \quad$ K 56 , p. 49o, l. 31.

$28 \quad$ K 56 , p. 495 , l. 35 .

$29 \quad$ K 56, p. 494, ll. 6-8.

$30 \quad$ Henning Brinkmann, 'Die Eigenform des mittelalterlichen Dramas in Deutschland', in Studien zur Geschichte der deutschen Sprache und Literatur, IV (Düsseldorf, 1966), pp. 193-231 (p. 209).

31 Ute von Bloh, p. 342.

32 Das Innsbrucker Osterspiel: Das Osterspiel von Muri, ed. by Rudolf Meier (Stuttgart: Reclam, 1980), vv. 362-70. 
Luciper rüeft die andern teuflen aus der helle und spricht: Wol her, wol her aus der helle, Allen mein lieben gesellen [...] Wir haben unsern vich gar verlorn Von dreien pösen weiben. Das sült ir all her wider treiben

Come to me, come to me from hell, my dear fellows, we have lost all our cattle to three evil women, you must drive them back. ${ }^{33}$

In $\mathrm{K}_{56}$, the theological program of the religious play is devalued by parody. The devils are no longer able to represent evil, being themselves too weak and sinful: they have become 'poor devils' and their powerlessness is total. Evil, here, has shifted onto the sly characters of the three old women-it has become human and subjective. Thus, Harlire can close the play by saying, in a disconcerting analogy to Jesus: 'O dear people, now look what great fun we old women have. The devil cannot resist against us' ('O lieben leut, nun secht an,/ Was großer lust wir alte weib han. / Der teufel mag uns nit wider streben'). ${ }^{34}$

The carnival play does not promise salvation to its audience. Rather, it plays intertextually with this kind of promise, excelling it on a fictional level. The play requires its audience members to agree to a theatrical 'as if' contract that they can easily decode, rather than to participate in a ritual from which they cannot take any distance. Thus the carnival play suspends the symbolic power of the Easter plays, destroying their seriousness and reducing the terror the Devil is able to incite. The derisive laughter that this play arouses is not at all ritualised. On the contrary, it mocks ritual with the help of both profanation and familiarisation. The devils of the Neidhart and Shrovetide plays have nothing to do with the devils of the religious plays, which can be characterised by their 'real presence' ('Realpräsenz');3 they are instead theatrical figures who have lost their ritual power. If this is so, it may be that devils in religious plays could also be perceived as such, a consideration that might shed light on the different kinds of laughter we saw above. Next to the fear-banning laughter for salvation there was laughter for comical causes (physical performances, 'split situation', carnival inversions) provoked by fictitious theatre figures who were played by locally known people. At the very least, carnival plays show that there was a consciousness of the fictional and of the theatrical in the staging of

\footnotetext{
$33 \quad$ K 56 , p. 492, ll. 7-9.

$34 \quad$ K 56 , p. 494, l. 34; p. 495, ll. $1-2$.

35 The term 'Realpräsenz' is used to illustrate the belief in the real presence of biblical characters on stage in an eschatological sense. See Jan-Dirk Müller, 'Realpräsenz und Repräsentation: Reale Frömmigkeit und Geistliches Spiel', in Ritual und Inszenierung, ed. by Ziegeler, pp. 113-33.
} 
characters that is responsible for these plays' increasing autonomy from ritual functions. ${ }^{36}$ By loosening the tight relationship of fear with evil, devil characters in the carnival plays become variables that increasingly leave the performance spaces to penetrate the secular context of everyday life.

\section{Devils, Devil Costumes, and Devil Masks in Urban Records of Carnival Rituals}

Theatre performances communicate with their audiences not only during the play, but also before and after. Were there mediating practices that modulated the relationship between what happened on and off stage? ${ }^{37}$ To conclude this essay, I will focus on devil costumes and masks that appeared off stage. Quite often, during carnival, there was an abuse of the devil's role and outfit, that resulted in mischief being made in public city spaces. Devil clothes, in particular, were much sought after goods - they were especially used during carnival mummeries, as mentioned in several council protocols, for instance in Freiburg (1566):

Es ist erkhanndt, die personen, so in den kleidern, die man im passion gepraucht, inn mumeri und butzenweise diese vaßnacht geloffen seindt etc., gefengklich inzelegen und zustrafen. Und uffs kunfftig jar die mumerey, butzen- und narrenweise ze lauffen getzlich abzestellen und zu verpieten.

It is known that the persons who, this Shrovetide, ran about in clothes that are normally used in the Passion play in order to mummer and disguise themselves, should be seized and jailed, and punished. ${ }^{38}$

More than a hundred years earlier, the city council of Basel had imposed a ban on running around in churches and in the city wearing devil masks and

36 The idea of 'literary' Shrovetide plays that take some distance from carnivalesque ritual dates back to Catholy: Eckehard Catholy, Das Fastnachtspiel des Spätmittelalters: Gestalt und Funktion, (Tübingen: Niemeyer, 1961), pp. 354 ff.

37 This is the question asked in Christopher Balme, The Theatrical Public Space (Cambridge: Cambridge University Press, 2014), p. 47.

38 Cit. from Geistliches Schauspiel im Zeugnis der Zeit. Zur Aufführung mittelalterlicher religiöser Dramen im deutschen Sprachgebiet, ed. by Bernd Neumann, I (München: Artemis, 1987), p. 346 (Freiburg im Breisgau; no. 1613). 
disguises: between 1420 and 1447, they imposed this ban at least five times. ${ }^{39}$ In Lucerne, from 1412 on there were several council bans on 'wild fool's activities' ('wildes gougkelwäsen'). ${ }^{40}$ Anyone appearing in the streets or in churches wearing a devil costume had to pay a severe penalty. As noted above, we know something about Lucerne devil disguises: they were made of fur, horns, cow tails, and animal teeth. The protocol of the general gathering that prepared the plays held in the wine market mentions the various uses for costumes. The Lutheran historian Cyriacus Spangenberg reports, in his Mansfeld chronicle (1590-160o), a disaster involving a 1488 Easter play produced in Hettstedt, another town in Thuringia, in the marketplace. Because the Hettstedt town council had punished an unnamed townswoman, she encouraged her sons to get even. Playing devils in the 1488 Easter play, Spangenberg reports, enabled them to run wildly through the streets and to set the whole town on fire. ${ }^{41}$

In 1566, in the Swiss town of Winterthur, devils set fire to their staged hell with gunpowder; the chronicler thanks God that nobody was seriously harmed. In 1527, in the town of Hof in Frankonia, the Catholic priest believed that, after the expulsion of the Protestant preacher, citizens were ready for a re-introduction of the sacred plays in order to re-establish the Catholic faith. When the play started with the 'Harrowing of Hell' on Easter Sunday morning in front of St. Michael, some younger spectators in devil disguises threw burning rags at the priest. ${ }^{42}$

In the town of Nördlingen in Thuringia, there were two incidents around the annual Corpus Christi procession. In 1502, a certain Leonhart Nesselhauf circulated in devil disguise, harassing 'women and virgins' ('frowen und iunckfrowen') with obscene words and gestures, for which he was jailed. In 1507, Daniel Frey 'went around in devil's clothes during the procession' ('hat in dem verganngen umbganng teufels klaider angehept und getragen'). Here the transgression seems to be the same: bothering and molesting women with inappropriate vocabulary. ${ }^{43}$

Why all these abuses of devil costumes and masks? What advantage did transgressors gain from wearing them? To think that it was just for fun or that it was simply a carnivalesque type of joking would not be sufficient and would

\footnotetext{
39 Neumann, p. 124 (Basel 1420; no. 43).

40 Heidy Greco-Kaufmann, Zuo der Eere Gottes, vfferbuwung dess mentschen vnd der statt Lucern lob: Theater und szenische Vorgänge in der Stadt Luzern im Spätmittelalter und in der Frühen Neuzeit (Zürich: Chronos, 2009), pp. 195-96.

41 Neumann, p. 405 (Hettstedt 1488, no. 1947).

42 Ibid., p. 407 (Hof 1527; no. 1951).

43 Ibid., p. 602 (Nordhausen 1502; no. 2331; Nordhausen 1507; no. 2332).
} 
hardly have had provoked such severe reactions from city rulers. Motives must have been both general and specific: general causes could well have been founded in medieval charivari culture: young men (women are never mentioned) disguised as devils participated in ritual group actions including begging (heischen), punishment, and harassment within the framework of local carnivalesque justice. ${ }^{44}$ Youths even went into houses to demand food and drinks, and would not depart before getting what they wanted. In this context there was occasion to abuse the rituals, particularly when they were used for private acts of revenge.

The devil's mask could thus lead its wearers from theatrical to real criminal action. The Lucerne council protocols report several cases of violent and harmful intrusions into private homes, and in 1412 a law was instituted that permitted the court to cite those people who were masked and mummered, insisting that they had to pay for what they destroyed. According to this law, devils in disguise were without rights. ${ }^{45}$ In 1396, three men (Uli Lütishofen, Hans Kramer, and Peter Scherer) entered, 'in devil's disguise' ('tüfels wise'), the house of Werner Keller's wife. They beat on her boards and closets with clubs and said that she had hidden to her husband that he lain with her 'as a child' ('kints lege'). This was probably a charivari-a publicly staged act of punishment in which a group of men in carnival clothes turned against someone (in this case a woman) who was believed to have bent or broken certain ritually instituted rules of moral behaviour (in this case marrying a man much younger than her). The goal of the three men was the public mocking and shaming of the rule-breaker. In this case, we can assume that the men made hellish noise and chaos' with their clubs, that they destroyed household objects, and that they menaced the woman. ${ }^{46}$ They likely wanted not only to scare the woman, but also to show that the Devil himself was called by these kinds of transgressions against normative public morality. The men thus made an example of this particular couple: by punishing a socially inappropriate marriage, they warned all women or widows against doing the same.

There is no record of whether these men were seized and punished or not. The whole event may have been tolerated by the authorities, given the mocking and farcical mode of the act, which could also have aroused aggressive laughter with bystanders or neighbours, as in mock rituals. Thus devil costumes allowed

The topic of carnivalesque ritual justice among youths is studied by Werner Röcke and Hans-Jürgen Bachorski, 'Verspielte Eh(r)e: Rügebräuche und "rites de passage" in Tanzund Fastnachtsspielen des Mittelalters', Paragrana, 11.1 (2002), pp. 103-32.

46 Ibid., p. 199 . 
individuals to play the role of the prankster outside the theatre. ${ }^{47}$ Here we are very far from the representation of evil in religious drama, but close to the Alsfeld devils who keep the order, more or less playing the role of moral police, a behaviour that is mirrored by the stage devils who drag sinners to hell.

As I have shown, devils off stage took advantage of emotional patterns established within the theatrical medium from which they came: their well-known disguise and movements, their noise, and their visual appearance might almost literally 'scare the hell out of people' in places where there is no theatrical framework whatsoever. These devils' ambivalent staging of effects that shift between fear and laughter can thus be used in a variety of ritual enactments that both mock and punish, and that require an ambivalence between seriousness and humour.

What the devil figure has lost off stage is his symbolic value as the representative of evil, both in religious and in ritual perspective. Council records and carnival plays highlight the depowering of a devil's force: when, in secular plays, he is shown as akin to foolish peasants; when he appears as inferior to ugly old women, beaten both physically and intellectually; and when he becomes a laughing-stock who is no longer dangerous to anyone, there is no pagan fear of him left.

If we apply these results to the question of the function of devil characters in religious plays, neither Warning's ritual theory nor Ohly's thesis of the Devil as fierce antagonist of God completely convince, because neither take seriously into account the staging of the devils and because both consider laughter ontologically. In my view, we must distinguish several forms of laughter that correspond to different occasions for laughter: Warning's ritual laughter can be seen in cheering the Devil when he acts as a hellish janitor, while Ohly's and

47 Which, as we have already seen, could sometimes slip into criminal action, as the $\mathbf{1 4 8 5}$ Bar-le-Duc case, reported by chronicler Philippe de Vigneulles, shows: 'There was performed in Bar-le-Duc a play in which there were several men playing the parts of devils. Amongst them, there was one who, in that get-up, wished to enjoy consortium with his wife. And she was putting him off and asking him what he was trying to do; and he responded: I wish, said he, to make the beast with two backs. And, hard as she tried to resist, she was forced to obey him.' Jody Enders, 'The Devil in the Flesh of Theater', in Transformationen des Religiösen, ed. by Kasten and Fischer-Lichte, pp. 127-38 (p. 128). 
Berger's Christian redemptive laughter arises when paschal joy concludes the play and the Devil is overcome by Jesus in the 'Harrowing of Hell'.

But there are still other sorts of laughter that respond to the devils' performance, specifically their physical acting, their obscene speech, their intellectual and moral inferiority - in short, their farcical side, which will later be taken up by fool characters. This is a type of laughter that arises from a theatrical figure with a mirror function, created in theatre for a theatrical audience and based mostly on physical comedy. This type of laughter does not work off stage, as we have seen, but wanders to the carnival stage to which it lends its arsenal of scenes and pranks, transforming the fearsome devil into a poor devil. And there is yet another kind of laughter that is directed to the actors playing devil roles: like other actors, they commit mistakes of declamation and movement, but the danger of ridicule is high with devils. If this kind of laughter succeeds, the whole theological program is jeopardised. Most importantly, it reveals the audience's awareness of the theatrical staging, which is a kind of reception we usually do not ascribe to medieval plays. This point seems to me highly important in the context of studies that examine the constitution of the public sphere through dramatic strategies.

Urban performances of religious and secular plays in the medieval tradition became bigger and more spectacular events in the fifteenth and sixteenth centuries, and the two kinds of theatrical entertainment interacted with each other in manifold ways. But they also became central events of urban self-representation, exceeding the limits of sacred contemplation and the certainty of salvation by establishing autonomous frameworks of theatricality and special effects. When devil scenes in Easter and Passion plays lose their representational character, become more profane and spectacular, and permit the figure of the devil to penetrate into secular plays, laughter transgresses its redeeming and ritual functions, diversifying and shifting to become a lookingglass for group and individual conflicts in the urban community. Laughter at the devil can therefore be seen as a medium of moral reflection: it circulates among the theatrical space of the performance and different public spaces, be it in carnival mockery and begging practices or in criminal action that enforces private interests. In this circulation of laughter as a performative statement I see a first step towards the constitution of an urban sphere of communication. It is a negotiation of the construction of evil, which is still dominated by corporeality and presence, but which laughter impacts, allowing a reflection upon the dissolving borders of social spheres and a pluralisation of the meaning of symbolic figures. 